\title{
Oil and Azadirachtin contents of neem (Azadirachta indica A. Juss) seed kernels collected from trees growing in different habitats in Sudan
}

\author{
Intisar Elnour ELTERAIFI ${ }^{1,2^{*}}$ and Ahmed HASSANALI ${ }^{1}$ \\ ${ }^{I}$ International Center of Insect Physiology and Ecology, P.O. Box 30772, Nairobi, Kenya. \\ ${ }^{2}$ Faculty of Agricultural Sciences, University of Gezira, P. O Box 20, Wad Medani, Sudan. \\ *Corresponding author, E-mail: esnrd@yahoo.com
}

\begin{abstract}
This study aimed to quantify and evaluate the level of Azadirachtin in neem seed kernel from ten ecotypes in Sudan over two seasons and establish relationship to the agro-ecological attributes. Extraction was done in two replicates using $12 \mathrm{~g}$. After extraction, separation and concentration to $10 \mathrm{ml}$ the samples quantified using HPLC. Neem trees growing in different habitats in Sudan showed variations in Azadirachtin (Az)- content depending on the climate, rainfall, soil type, latitude and altitude. The Az-content ranged from $1.08-2.3 \mathrm{mg} / \mathrm{g}$ of the seed kernel in the first season and from $0.48-3.09 \mathrm{mg} / \mathrm{g}$ in the second season. The average content of neem oil was $44.6 \%$ in the neem seed kernel (NSK); no variation was found between these regions in oil- content. Trees growing in regions with moderate climate, average rainfall of $400 \mathrm{~mm}$, and altitude of $>470 \mathrm{~m}$ above sea level, proved to be rich in Az- content. However, trees growing in lower altitudes, alluvial or sandy soil, with hot climate reflected very low Az- content. Rainfall was found to be the major factor affecting the level of Az in NSK, and the optimal rainfall was $717 \mathrm{~mm}$. Temperature and relative humidity had no direct effect on the Az-content. However, the combination of temperature and the rainfall showed a positive correlation with the Az level in NSKs. Latitude and altitude have direct effect on Az level. Seasonal variations were clear over the two seasons, and no relationship was found between the two seasons. (C) 2011 International Formulae Group. All rights reserved.
\end{abstract}

Keywords: Neem, Azadirachtin, ecotypes, ecological variations, Sudan.

\section{INTRODUCTION}

Neem (Azadirachta indica A. Juss, Meliaceae) is known to be an important source of triterpenoids (Mary Ndung'u, 2004) meanwhile; it is one of the most promising under-exploited plants of the tropics (Hassanali, 1983). The centers of origin lie between Southern and South Eastern Asia (Schmutterer, 1990). Neem extracts and compounds have attracted the special interest of entomologist and phytochemists all over the world (Kraus, 1995; Schmutterer, 1990;
Jacobson, 1988). These extracts possess insect repellents, antifeedants, growth inhibitors and other insecticidal properties (Saxena, 1989; Schmutterer, 1990; Schmutterer, 1995 and Singh, 1993). Neem seed kernel (NSK) is the most important source of triterpenoids (Kraus et al., 1981; Kumar et al., 1996) and azadirachtin $(\mathrm{Az})$ is considered to be the compound of the most biological interest (Donald et al., 1992; Kraus, 1995; Saxena et al., 1989). Azadirachtins are steroid-like tetranotriterpenoids formed by a group of 
closely related isomers, called Azadirachtin-A to Azadirachtin-G (Rembold et al., 1984; Rembold et al., 1987). Several other active compounds were isolated from NSKs, such as salannin, gedunin and nimbin (Jones et al., 1989). Az is a highly oxidized triterpenoid and one of the most potent antifeedant compounds yet discovered (Hassanali, 1983) and it affects the normal growth and development of a wide spectrum of insects (Schmutterer, 1990; Mordue and Blackwell, 1993; Schmutterer, 1995). However, its lability to heat, moisture, air, etc. has been a matter of concern that led to global efforts to stabilize it (Stark and Walter, 1995; Raguraman and Jayaraj, 1994; Stokes and Redfern, 1982; Barnby et al., 1989). Az represents about $0.2-0.8 \%$ of the seeds by weight, and it is accompanied by a number of other triterpenoids, such as nimbin (Harris et al., 1968) and salannin (Henderson et al., 1968), which exhibit similar biological properties, to a greater or lesser extent.

The amount of $\mathrm{Az}$ may vary considerably, depending on environmental and genetic factors. Az varies greatly among different trees and regions or countries (Ermel et al., 1984; Ermel et al. 1987; Ketkar and Ketkar, 1993). Samples from 22 countries were investigated by Ermel (1995) for more than 4 years showed marked variations between samples from different countries and among samples from the same country with mean value of $3.6 \mathrm{mg} / \mathrm{g}$ of $\mathrm{Az}$ and $46.7 \%$ neem oil (N.O.). The highest content of $\mathrm{Az}$ (10 mg/g seed kernel) was recorded by Shaun et al. (1996) in newly ripened seeds; there was some loss of $\mathrm{Az}$ and salannin in storage after harvesting for up to 6 months. Az- A is the currently accepted reference ingredient for standardizing neem-based products (GTZUNIDO-RENPAP, 1996).

Synthetic pesticides possess quick knock down effect, but they are often toxic to mammals and non-target organisms (Klassen et. al., 1986; Marquis, 1986). Safe ecological pesticides that do not leach residues into the environment have great importance (Cook and Baker, 1983).
Large quantities of synthetic pesticides are imported to Sudan which is basically dependent on Agriculture as one of the main economic factors. These pesticides have a negative impact on the environment and human health.

Neem biopesticides will be part of the appropriate solution for these environmental problems. This study is an attempt to generate prerequisite information on this valuable tree by quantifying the most active ingredient Azadirachtin and to relate it to the most effective ecological factors to generate elite trees for future plantations.

\section{MATERIALS AND METHODS \\ Study area}

All samples in this study were collected in Sudan located between latitude 3' 35'and $22^{\prime} 35^{\prime}$ North and longitudinal area between $22^{\prime} 38^{\prime}$ East, with a total area of $2,505,813$ square kilometers

\section{Experimental materials Neem seeds}

Ten agroecological zones were selected for neem seed collection according to the tree seed zoning systems map (DANIDA/ARC, 1995). These regions cover the whole country except the South (Table 1). Seeds were collected over two seasons.

Neem fruits were collected from neem plantations at the selected zones (Table 1). Four sites within each zone were selected randomly and 15-20 trees were marked randomly in each site. In total, $2-3 \mathrm{~kg}$ of the neem fruits were collected from the marked trees. Collected fruits were then transported to the National Tree Seed Centre, Soba-Sudan, where they were cleaned in the processing room and dried under shade in dry weather. Seed processing was carried in accordance with International Seed Testing Association (ISTA) (1996) and International Neem Network recommendations (Thomson and Souvannavong, 1994). A sample of 500 grams was drawn from each lot using the seed divider and stored at $4{ }^{\circ} \mathrm{C}$ till it was taken to the Behavioral and Chemical Ecology 
Department (BCED) laboratory at International Center for Insect Physiology \& Ecology ICIPE-Kenya.

\section{Moisture content determination}

Samples of 15 seeds replicated 4 times were drawn for moisture content determination in accordance with ISTA (1996) low constant temperature method (103 $\pm 1^{\circ} \mathrm{C}$ for $17 \pm 1 \mathrm{hrs}$ ). The moisture content was calculated on a wet weight basis.

\section{Chemicals}

Laboratory-grade reagents and solvents used in extractions were methanol $\left(\mathrm{CH}_{3} \mathrm{OH}\right)$ purity $99 \%$, hexane $\left(\mathrm{CH}_{3}\left(\mathrm{CH}_{2}\right)_{4} \mathrm{CH}_{3}\right)$ (purity $99.8 \%$ ) and distilled and deionized water. Appropriate analytical-grade solvents were used in high pressure liquid chromatography (HPLC) acetonitrile (HPLC grade) and distilled in deionized water.

The standard substances azadirachtin A and B (96\% purity), was bought from TrifoloM-GmbH (Lahnau, Federal Republic of Germany). $1.00 \mathrm{mg}$ of each was dissolved in 5 $\mathrm{ml}$ of methanol.

\section{Extraction}

Extraction was done from two replicates; $12 \mathrm{gm}$ of each sample was extracted with $25 \mathrm{ml}$ of methanol in a $250 \mathrm{ml}$ conical flask and stirred magnetically for $2 \mathrm{hrs}$. The extraction was repeated two times (for $1 \mathrm{hr}$ each). The pooled methanol extract was shaken with $30 \mathrm{ml}$ of hexane and $1.0 \mathrm{ml}$ of distilled water. Extraction with hexane was repeated two times. Two layers were obtained in each case, the upper mainly hexane layer was separated from the lower aqueous methanol layer. The latter was concentrated in vacuo to $10 \mathrm{ml}$ and stored at ($15^{\circ} \mathrm{C}$ ) for high performance liquid chromatography

The residual kernel powder was then reextracted with hexane (three replicates $30 \mathrm{ml}$ each). The upper hexane layers from above were mixed with the hexane layer obtained earlier and concentrated in vacuo to give the oil. All oil samples prepared were stored at $-15^{\circ} \mathrm{C}$.

\section{HPLC}

Analytical High Performance Liquid Chromatography (Beckman HPLC, System Gold) (HPLC) separation was performed on ODS columns, ultrasphere C-18, 250×4.6 mm, programmed as follows: $40 \%$ acetonitrile in water $(10 \mathrm{mn}$.) to $70 \%$ acetonitrile (10 $\mathrm{min}$.) and finally to $100 \%$ acetonitrile ( $5 \mathrm{~min}$.), all at $1 \mathrm{ml} / \mathrm{min}$. The eluents were monitored at 214 nm. Quantification of the azadirachtin was based on injections of known quantities of standard samples.

The ultra-violet spectra of crude substances were determined using an on-line diode array detector on a running on acetonitrile/water solvent system. Each sample was analyzed three times.

\section{Meteorological data}

Meteorological (rainfall, temperature and relative humidity) and geographical positioning (GPS) data (latitude, longitude and altitude) for the selected agro-ecological zones were obtained from the Metrological Department of Sudan.

\section{Statistical analysis}

The effect of zone on the Azadirachtin content of the neem seed kernels were analyzed using 2-way ANOVA. Means were separated using the Tukey test. Data were analyzed using SAS (SAS, 1987). Separation of means of Azadirachtin was carried out using Tukey's Studentized Range test (HSD) where data were balanced $(\mathrm{P}=0.05)$ to compare the Azadirachtin content in the different zones. Correlation and multiple regression analysis were also carried using the same software to find the relations between the meteorological data, geographical positioning data and the Azadirachtin contents. GLM and PCA procedures were also used for the regression models and the grouping of factors respectively.

\section{RESULTS}

Variation in the Az- level between regions Samples of NS from different regions were investigated for two successive seasons. NS were dried, decorticated and extracted at 
room temperature by using methanol $(\mathrm{Me} . \mathrm{OH})$. Fig. 1 shows the variations in the $\mathrm{Az}$ - level in the different regions over the two seasons.

There was variation in $\mathrm{Az}$ - level between different regions in the Sudan (C.V.= $25.65 \%$ and C.V.=16.96, for the two seasons, respectively; (Fig. 1). The Az- content varied from $1.0771 \mathrm{mg} / \mathrm{g}$ to $2.3444 \mathrm{mg} / \mathrm{g}$ for the first season and from $0.476 \mathrm{mg} / \mathrm{g}$ to $3.091 \mathrm{mg} / \mathrm{g}$ the second season. Moreover, there were significant variations between the different sites within the regions, and between the trees within the sites. The values for the two seasons regarding the Az- level varied from $1.78 \mathrm{mg} / \mathrm{g}$ in the first season, to $1.57 \mathrm{mg} / \mathrm{g}$ in the second season.

Effect of the metrological and geographical factors on Az-level in NSK

Different metrological factors were used in simple and multiple regressions to find out the possible relations of these factors with Az-level in NSK from different regions. Namely, these factors were rainfall, temperature and R.H., in addition to latitude, longitude and altitude.
There was no significant effect for the temperature on level of Az in NSK. However, the rainfall was significantly affecting $\mathrm{Az}$ concentration, and the optimum rainfall was found to be $717.9 \mathrm{~mm}$. The R.H. showed no significant effect on the Az-level, while the altitude affected it significantly (Table 2).

There was a significant negative relationship between the $\mathrm{Az}$ and the latitude. However, altitude showed a significant positive effect on Az-content, and the longitude did not. Although no significant correlation was found between the Az-content and the temperature, but there was a significant effect from the combination of the temperature and the rain fall on the Az-level $(\mathrm{P}=0.038)$.

\section{Neem Oil (N.O.)}

The N.O.-content varied from 47.4- to$41.1 \%$, but no variation was found between the different ecotypes of the NSK.

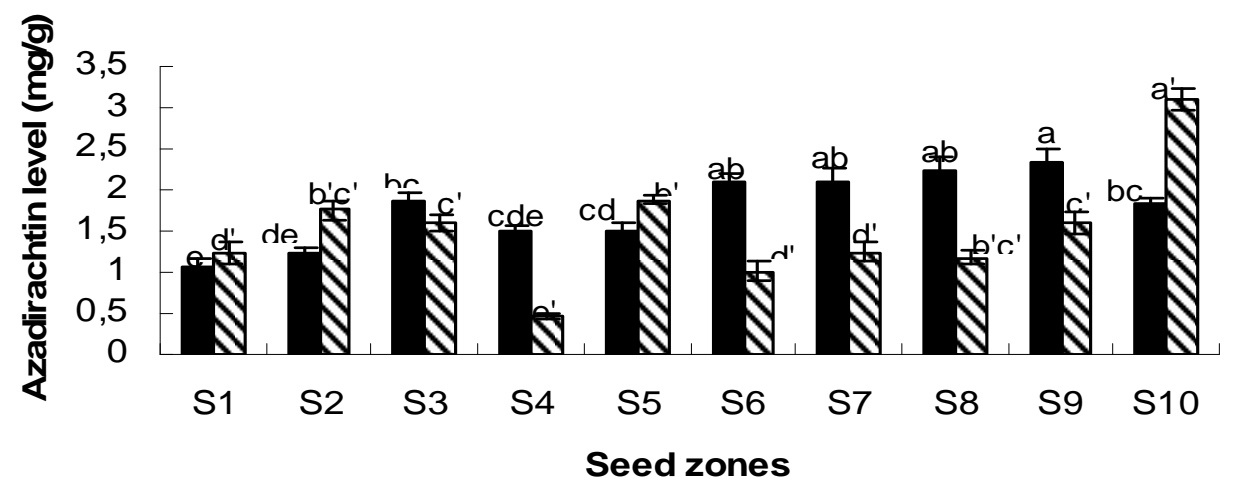

Season 2001 \ Season 2002

Figure 1: Variation of the Azadirachtin level (mg/g) from different ecotypes in Sudan for two seasons.

Columns with the same letter are not significantly different at a probability level of 5\%. 
I. E. ELTERAIFI and A. HASSANALI / Int. J. Biol. Chem. Sci. 5(3): 1063-1072, 2011

Table 1: Agro-ecological zones for neem seed collections.

\begin{tabular}{|c|c|c|c|c|c|c|c|c|}
\hline $\begin{array}{l}\text { Seed } \\
\text { code }\end{array}$ & Vegetation type & Agro-ecological zone & Latitude $\mathbf{N}^{*}$ & Longitude $\mathbf{E}^{*}$ & $\begin{array}{l}\text { Altitude } \\
\text { (a.s.l.) } *\end{array}$ & $\begin{array}{l}\text { Mean } \\
\text { annual } \\
\text { rainfall } \\
(\mathrm{mm}) *\end{array}$ & $\begin{array}{l}\text { Mean } \\
\text { annual } \\
\text { temp. } \\
\left({ }^{\circ} \mathrm{C}\right) *\end{array}$ & $\begin{array}{l}\text { Relative } \\
\text { humidity } \\
\% *\end{array}$ \\
\hline S1 & $\begin{array}{l}\text { Vegetation confined to } \\
\text { watercourses; Phonex spp. \& } \\
\text { Acacia spp. }\end{array}$ & Desert & $1910^{\prime}$ & 3029 ' & 228 & 12.3 & 27.3 & 25 \\
\hline $\mathrm{S} 2$ & $\begin{array}{l}\text { Acacia tortilis, Maerua } \\
\text { crassifolia \& other desert } \\
\text { shrubs. }\end{array}$ & Semi desert & $1734^{\prime}$ & $3356^{\prime}$ & 350 & 39.4 & 29.4 & 25 \\
\hline S3 & $\begin{array}{l}\text { Acacia spp. \& other trees } \\
\text { planted for shade }\end{array}$ & Semi desert & $1536^{\prime}$ & $3233^{\prime}$ & 380 & 162.4 & 29.9 & 29 \\
\hline S4 & $\begin{array}{l}\text { Acacia melifera, Acacia } \\
\text { nilotica and other semi desert } \\
\text { spp. on clay }\end{array}$ & Semi desert on clay & $1425^{\prime}$ & 3329 ' & 405 & 306.4 & 28.6 & 39 \\
\hline S5 & $\begin{array}{l}\text { Acacia Senegal, Adonseiana } \\
\text { digitata \& other semi desert } \\
\text { spp. on sand }\end{array}$ & $\begin{array}{l}\text { Central A. senegal } \\
\text { savanna }\end{array}$ & $1310^{\prime}$ & 3014 & 570 & 318.0 & 27.3 & 34 \\
\hline S6 & $\begin{array}{l}\text { Acacia spp. on semi desert } \\
\text { grass land on sand }\end{array}$ & Semi on sand & ‘ & ' & & & & \\
\hline S7 & $\begin{array}{l}\text { Acacia seyal, Balanities } \\
\text { egyptiaca \& other Acacia spp. }\end{array}$ & $\begin{array}{l}\text { Central to eastern } A \text {. } \\
\text { seyal-Balanities wood } \\
\text { land }\end{array}$ & ' & ' & & & & \\
\hline
\end{tabular}


I. E. ELTERAIFI and A. HASSANALI / Int. J. Biol. Chem. Sci. 5(3): 1063-1072, 2011

\begin{tabular}{|c|c|c|c|c|c|c|c|c|}
\hline S8 & $\begin{array}{l}\text { Anogeissus spp., Comberatum } \\
\text { hartmannium \& Acacia spp. }\end{array}$ & $\begin{array}{l}\text { Eastern deciduous } \\
\text { Anogeissus/Comberetu } \\
m \text { wood land }\end{array}$ & $1149^{\prime}$ & $3424^{\prime}$ & 470 & 712.9 & 28.3 & 47 \\
\hline S9 & $\begin{array}{l}\text { Khaya seglensis, Combertum } \\
\text { spp. \& Anogeissus spp. }\end{array}$ & $\begin{array}{l}\text { Darfur-western } \\
\text { Kordofan Deciduous } \\
\text { wood land }\end{array}$ & $1204^{\prime}$ & $2453^{\prime}$ & 655 & 398.3 & 27.2 & 31 \\
\hline S10 & $\begin{array}{l}\text { Broad-leaved trees; } \\
\text { Anogeissus spp. \& } \\
\text { Combertum spp. }\end{array}$ & $\begin{array}{l}\text { Nuba mountain hill } \\
\text { catena }\end{array}$ & $1100^{\prime}$ & $2943^{\prime}$ & 500 & 633.1 & 28.1 & 47 \\
\hline
\end{tabular}

Table 2: Simple correlation matrix between Azadirachtin level and some ecological factors in Sudan.

\begin{tabular}{lc}
\hline Factor & Azadirachtin \\
\hline Temp & $-0.006^{\mathrm{NS}}$ \\
RF & $0.738^{*}$ \\
R H & 0.513 \\
Alt. & $0.725^{*}$ \\
Lat. & 0.790 \\
\hline Values with & NS and * are respectively not significant and significant at a probability level of $5 \%$.
\end{tabular}




\section{DISCUSSION}

Samples of NS from different regions in the Sudan were investigated intensively for two successive seasons. The results showed great variations in the active ingredient, Azcontent, between the different seeds, which were collected from different ecological and geographical zones, and between the two seasons. Similar results were reported by other investigators (Ermel et al., 1984, and 1987). Ermel (1995) investigated different samples from different parts of the world and showed great variations between and within countries. These variations could be attributed to the edaphic and climatic factors, which vary in Sudan from the desert in the upper north, to the humid Savanna in the Southern, and from hilly areas in the Western to open plains in the Central and Eastern parts. These results were also in line with other detailed investigations of Gruber (1991) on Az-content of 47 marked trees from five locations in Nicaragua over a period of 4 years. This study revealed a great influence of edaphic climatic factors on the synthesis and degradation of Az.

A variation was established between the ecotypes within the regions, and even between the trees in the same site. Large variations in the Az-content (2895 to 7525 ppm) have also been observed in the NSK of the different ecotypes of Tamil Nadu (Kumar and Parmar, 1996). Very few studies have been carried out so far in the world to detect the existing variability of Az- content in neem trees, and even fewer on oil-content variability. Ermel et al. (1987) determined Azcontents in NS of different countries and found that the highest yield of Az-content per NSK is not restricted to a specific country, but it is distributed in single trees of different origin. Rengasamy et al. (1993) reported that the neem ecotypes of India showed varying Az-content (0.14 to $1.66 \%$ ), which was also in line with the present work results. Therefore, it is now established that there is great variation between ecotypes within the regions and between the different trees growing in the same site.

No variation was found between different regions in the oil-contents. The same results were obtained by Ermel (1995) where he found the variations in oil-content was less than those in Az. Moisture-content is an affecting factor on the oil-content, and further relationships are needed to find out the most affecting factors. In contradiction to this result, Rengasamy et al. (1993) found that the oils of different ecotypes showed different Az-content and physico-chemical properties in India. However, no correlation was found between the oil- and Az-content (Ermel, 1995).

The Az-content was found to be affected by rainfall and altitude. Regions with moderately high rainfall proved to be rich in the Az-content; while regions with hot dry weather were reported to have lower content of Az. Seasonal and annual variations in the Az-content were also observed over the country. Same results were obtained with other investigations in India carried out by Rengasamy et al. (1993) in which they mentioned that ecotypes growing in regions with moderate climate, red and shallow medium soils, and altitudes up to $500 \mathrm{~m}$ (a.m.s.l.) were rich in Az-content. Ecotypes growing in high altitude alluvial soils, with extremely hot and cold climates, were poor in Az-content. These studies lack detailed meteorological data with correlations to the Az-contents, and can be taken for general hints. On the other hand, efforts are underway at CRIDA, Hyderabad, on correlating the different factors, e.g. soil type, rainfall, and R.H. with the Az-content in the seeds for trees growing in different parts of Andhra Pradesh state These studies suggest that there is a need to do the chemical evaluation of the seeds from diverse zones to identify neem trees having high amounts of oil and $\mathrm{Az}$ to make the plant economically more attractive. 
The results show a significant positive effect of the rainfall on the active ingredient, while temperature has no direct effect on it. However, there was a significant effect of the combination of the temperature and the rainfall on Az. This result matched the findings of Baumgart (1991) in Benin, where they found in areas with a high rainfall, $\mathrm{Az}$ values tended to increase. In constrast Singh (1987) reported a high antifeedant activity of extracts from kernels of neem trees growing in arid areas of India, when compared with those growing in coastal areas.

$\mathrm{Az}$ was found to be significantly affected by the latitude with a negative relationship. Az increases from Northern Sudan toward the Southern parts, which follows the same trend of the rainfall.

It is found also that altitude has a positive and significant effect on the Azcontent, while the R.H. and longitude have no effect on the content. The same results were found by Rengasamy et al. (1993) for the altitude even though we had a positive correlation. Also, according to those authors Az-content increases up to altitude $500 \mathrm{~m}$ (a.s.l) and at higher altitude the $\mathrm{Az}$ content became low in relation to the type of the soil.

There is increasing demand for quality planting material for neem plantations. However, individual neem trees vary in their chemical make-up as the oil-content and limonoids-content of neem trees are governed by genetic and environmental factors. Efforts are lacking for the selection of neem trees based on Az-content and the oil-content. The present study provides some of the needed information for such selections for the new plantations.

\section{REFERENCES}

Barnby MA, Yamasaki RB, Klocke JA. 1989. Biological activity of azadirachtin, three derivatives and their ultraviolet radiation degradation products against tobacco budworm (Lepidoptera: Noctuduidae) larvae. J. Appl. Entomol., 82: 58-63.

Baumgart M. 1991. Das Niemvorkommen in der republic Benin, Deutsche Gesellschaft fur Technische Zusammenarbeit. Eschborn; 61.

Cook RJ, Baker KF. 1983. The nature and practice of biological control of plants pathogens. In The American Phytopathological Society. St. Paul MN.

DANIDA/ARC 1995 Report Tree seed project seed zoning system. ARC/Sudan publications.

Donald E, Champagne Opender K, Murray B, Isman G, Scudder GE, Neil Towers GH. 1992. Bilogical activity of limonoids from Rutales. Phytochemistry, 31(2): 377-394.

Ermel K. 1995. Azadirachtin content of neem seed kernels from different regions of the world. In The Neem Tree, Schmutterer H (Ed); 89-92.

Ermel K, Pahlich E, Schmutterer H. 1984. Comparison of azadirachtin content of neem seeds from ecotypes of Asian and African origin. Proc. 2nd Int. neem Conf., Rauischholzhausen, Germany; 91-94.

Ermel K, Pahlich E, Schmutterer H. 1987. Azadirachtin content of neem kernels from different geographical locations and its dependence on temperature, relative humidity and light. Proc. 3rd Neem Conf., Nairobi, Kenya; 171-184.

GTZ-UNIDO-RENPAP. 1996. Symposium on analysis and standardization of neem extracts. Pleizhausen Stuttgart, Germany, Oct. 16-17.

Harris M, Henderson R, McCrindle M, Overton KH, Turner DW. 1968. Tetranortriterpenoids VIII. The constitution and stereochemistry of Nimbin. Tetrahedron, 24: 1517-1523.

Hassanali A. 1983. The Neem (Azadirachta indica. Tree as a Source of anti-pest agents. Proceedings of the Africa Seminar on the Use and Handling of Agricultural 
and other Pest Control Chemicals, Malavet L, Muchiru S, Wright H, (Eds). 30th Oct. - 4th Nov. 1983, Duduvile, Nairobi; 131-136.

Henderson R, McCrindle M, Melera A, Overton KH. 1968. Tetranortriterpenoids IX. The constitution and stereochemistry of Salannin. Tetrahedron, 24: 1525-1528.

ISTA. 1996. Seed Sciences and Technology, Zürich, Switzerland.

Jacobson M. 1988. Focus on Phytochemical Pesticides. The Neem Tree (Vol. 1). CRC Press: Boca Raton. FL.

Jones PS, Ley SV, Morgan ED, Santafianos D. 1989. Focus on Phytochemical Pesticides. The Neem Tree (Vol. 1); CRC Press: Boca Ranton, FL; 19-45.

Ketkar CM, Ketkar MS. 1993. Azadirachtin contents of neem and its by-products from different parts of India. World Neem Conference (Bangalore, India); 54.

Klassen CD, Amdur MO, Doull J. 1986. Casarett and Doull's Toxicology: The Basic Science of Poisons. MacMillan Publishing: New York.

Kraus W. 1995. The Neem Tree; Source of Unique Natural Products for Integrated Pest Management, Medicine, Industry and Other Purposes, Schmutterer H (ed). VCH Weinheim, FRG; 35-88.

Kraus W, Carmer R, Sawitzki G. 1981. Tetranotriterpenoids from the seeds of Azadirachta indica. Phytochemistry, 20:117-120.

Kumar CSSR, Srinivas M, Yakkundi S. 1996. Limonoids from the seeds of Azadirachta indica. Phytochemistry, 43(2): 451-455.

Kumar J, Parmar B. 1996. Physicochemical and chemical variation in neem oils and some bioactivity leads against Spodoptera litura F. J. Agric. Food Chem., 44: 21372143.

Marquis JK. 1986. Contemporary Issues In Pesticide Toxicology and Pharmacology. Karger: Basel, Switzerland.
Mary Ndung'u, Baldwyn Torto, Bart GJ. Knols, Ahmed Hassanali. 2004. Laboratory evaluation of some eastern African Meliaceae as sources of larvicidal botanicals for Anopheles gambiae. International Journal of Tropical Insect Science, 24: 311-318.

Mordue (Luntz) AJ, Blackwell A. 1993. Azadirachtin: an update. Insect Physiology, 39: 903-24.

Raguraman S, Jayaraj S. 1994. Effect of neem products on the population dynamics of wolf spider, (Lycosa psseudoannulata). Neem News 1, 11(1): 4-6.

Rembold H, Forster H, Czoppelt Ch. 1987. Structure and biological activity of Azadirachtin A and B. Natural pesticides from the neem tree and other tropical plants; Proceeding of the 3nd International Neem Conference, Nairobi, 1986; GTZ: Eschborn, Germany; 149160.

Rembold H, Forster H, Czoppelt Ch, Rao JP, Sieber KP. 1984. The Azadirachtins, a group of insect growth regulators from the neem tree. Natural pesticides from the neem tree and other tropical plants; Proceeding of the 2nd International Neem Conference, Rauischholzhausen, 1983; GTZ: Eschborn, Germany; 153-162.

Rengasamy S, Kaushik N, Kumar J, Koul O, Pamar BS. 1993. Azadirachtin content and bioactivity of some neem ecotypes of India. In Neem and Environment (Vol. I), Singh RP, Chari MS, Raheja AK, Karus W (Eds). Scientific Publisher INC: USA; 207-217.

SAS Institute, SAS user's guide: Statistics; SAS institute: Cary, NC, 2001.

Saxena RC. 1989. Insecticides from Neem. In Insecticides of Plant Origin. Arnason JT.

Schmutterer H. 1995. Insecta, insects In: The Neem Tree, Schmutterer H (ed). VCH Weinheim; 167-365.

Schmutterer H. 1990. Properties and potential of natural pesticides from the neem tree, 
Azadirachta indica. Annu. Rev. Entomol., 35: 271-297.

Singh RP. 1987. Comparison of antifeedant efficacy and extract yields from different parts and ecotypes of neem (Azadirachta indica A. Juss) trees. Proceeding of Third International Neem Conference, Nairobi, 1986; Schmutterer, H. and Ascher, K. R. S. (Eds). Germany Agency for Technical Cooperation: Eschborn, Germany; 185194.

Singh RP. 1993. Bioactivity against insect pests. In Neem Research and
Development, Randhawa NS, Parmar B (Eds). Publication 3 Society.

Stark JD, Walter JF. 1995. Persistence of Azadirachtin-A and B in Soil: Effects of temperature and microbial activity. $J$. Environm. Sc. Health, 30B(5): 685-698.

Stokes JB, Redfern RE. 1982. Effect of sunlight on Azadirachtin. Antifeedancy potency. J. Environm. Sc. Health, 17A(1): 57-65. 